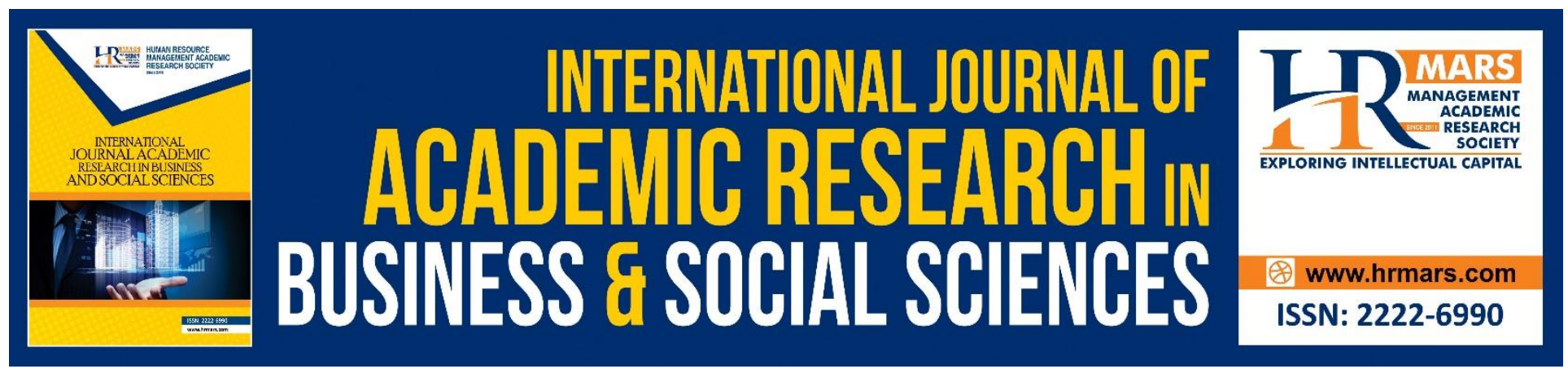

\title{
Empowerment of Women for Economic Development in the Aic, Kapseret Sub County Uasin Gishu, Kenya
}

Jepchirchir Lydia, Anthony Oure Ichuloi, Julia Situma

To Link this Article: http://dx.doi.org/10.6007/IJARBSS/v10-i11/8082

DOI:10.6007/IJARBSS/v10-i11/8082

Received: 17 September 2020, Revised: 30 September 2020, Accepted: 18 October 2020

Published Online: 16 November 2020

In-Text Citation: (Lydia, Ichuloi, \& Situma, 2020)

To Cite this Article: Lydia, J., Ichuloi, A. O., \& Situma, J. (2020). Empowerment of Women for Economic Development in the Aic, Kapseret Sub County Uasin Gishu, Kenya. International Journal of Academic Research in Business and Social Sciences. 10(11), 277-291.

\section{Copyright: (c) 2020 The Author(s)}

Published by Human Resource Management Academic Research Society (www.hrmars.com)

This article is published under the Creative Commons Attribution (CC BY 4.0) license. Anyone may reproduce, distribute, translate and create derivative works of this article (for both commercial and non-commercial purposes), subject to full attribution to the original publication and authors. The full terms of this license may be seen

at: http://creativecommons.org/licences/by/4.0/legalcode

Vol. 10, No. 11, 2020, Pg. 277 - 291

http://hrmars.com/index.php/pages/detail/IJARBSS

JOURNAL HOMEPAGE

Full Terms \& Conditions of access and use can be found at http://hrmars.com/index.php/pages/detail/publication-ethics 


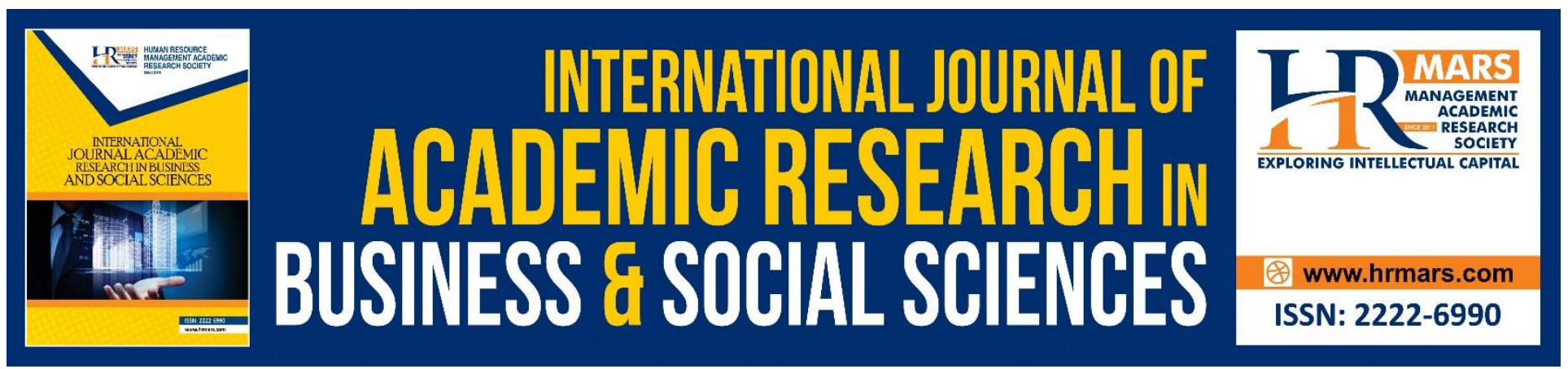

\title{
Empowerment of Women for Economic Development in the Aic, Kapseret Sub County Uasin Gishu, Kenya
}

\author{
${ }^{1}$ Jepchirchir Lydia ${ }^{2}$ Dr. Anthony Oure Ichuloi, ${ }^{3}$ Dr. Julia Situma \\ ${ }^{1}$ Degree of Masters of Arts in Religion of the School of Arts and Social Sciences, ${ }^{2}$ Lecturers Kisii \\ University, ${ }^{3}$ Lecturers Kisii University
}

\begin{abstract}
The mission of the Church is that of liberating people enslaved by various forces; it is the mission of Jesus, witnessing to God's incarnate love for the development of humanity. Economic development cannot only be left to the government, the Church apart from her spiritual mission, is also challenged to enhance economic development of society. The objective of the study was to evaluate the empowerment of women for economic development in the AIC in Kapsaret sub-county. The guiding theory for this study was alternative development theory. The study was enucleated by Communitybased Qualitative Research (CBQR) method, adopting a descriptive research design. The study employed two data collection tools: the questionnaire and interview schedule guide. The researcher conducted a pilot study with A.C.K Mai-Mahiu to ascertain the reliability and validity of research instruments. Data analysis entailed the use of both qualitative and quantitative techniques, which was done using Statistical Package for Social Science (SPSS) version 23.0 and descriptive statistics for quantitative data. The study findings revealed that the church has programs that provide employment opportunities to both women and the youths in the community. The study concluded that the empowerment of women is indispensable for community integral development in Kapseret Sub-county. The AIC development initiatives are far reaching to economic empowerment of women and youth, which takes development to the grassroots. The study recommended that the AIC needs to come up with more robust faith-based programmes that can provide employment opportunities to many other community members that will impact society by reducing the poverty level in the area. Keywords: Empowerment, Women, Development, AIC, Economic
\end{abstract}

\section{Background of the Study}

In modern society, with the exponential population growth, responding to the people's basic development needs is a call to all institutions. This call demands that institutions cooperate in providing solutions to problems that affect society, particularly in economic development. This implies that economic development is not a reservoir of the government alone, excluding the affected people's participation. True and sustainable economic development should not be interpreted "outside" of the community. Still, it should include the inward-looking element, from 
both political arrangements and the local community and private institutions that work on the same (Brown \& Schafft, 2011).

The meaning of the Church can only be read in the context of her mission by Jesus. Jesus took into account his followers' physical and economic needs by feeding the hungry, healed the sick, taught his disciples to pray, cast out demons, took care of the poor, and so on. This missionary methodology started by Jesus covered all aspects of human life, which implicates his disciples' community to do the same. This is where any faith-based institutions for them to positively impact people's lives, particularly economic development in the 21st century, should take into account the local community and local resources as the grassroots pillar of development (Scazzero, 2011). Local community development enhances the resilience of the needy people leading to greater economic embrace and change since it takes into account the collective efforts of members that are the direct beneficiaries (Christens, 2012).

It is because of this that many institutions, including the government, look upon the Church for socioeconomic development that can bring tangible positive changes to the lives of the communities that they serve (Ghai \& Vivian, 2014). The positive contribution of the Church to the socio-economic and political development of communities makes the Church a leading and admired institution in the area of development (Kuperus, 2011). Her involvement in development demonstrates a social and liberating process that brings justice, self-reliance and economic growth of those that are either directly or indirectly affected. This involvement is realized through the formation of local development groups formed that are aimed at strengthening the abilities of the local communities to solve their own economic needs without the attitude of dependence on others.

This role of the Church in promoting faith-based development is furthermore recognised by African governments and international bodies, thus giving rise to increased participation of Church-related organisations in promoting economic development in the continent. Embracing Western faith-based approach to development had the weakness focusing more on foreign help while undermining homegrown involvement to development. The African Church is more of outward-looking Church curtailed by her poverty reality to look inward herself and her reality. Scholars argue that lack of socio-economic stability in the African Church and most communities is brought about by lack of community involvement, proper education, community sensitisation and sufficient local economic income (Fukuyama, 2010; Fagan, 2014).

In Kenya, the role of the church in community development has been practised since the coming of the white missionaries without much of local participation. All over the country, Christian missionaries played a major role in the construction of hospitals, schools, orphanages for the sick, aged and children, charity church institutions, etc. Today, these institutions are managed by the local church, while others have been taken up by the Government to manage. Oliver et al. (2015) assert that the AIC in Kenya is increasingly becoming involved in the economic and social development of the local communities entrusted to her by the early missionaries. However, this spirit is adversely affected by the high poverty in the areas of her mission, the local church contribution is just microcosm and therefore not enough to support all the activities of the church; the local church lacks resources to address the multiple needs of society.

\section{Statement of the Problem}

The community development role is all combined missions where all institutions in their specific areas of engagements are called to realize. However, the Church, as an institution, has a global or all- 
encompassing mission'. She is called to promote the integral development of society members as her mission given to them by her master, Jesus. At the same time, the Church is challenged to fight for economic justice for all and be an agent of economic development.

However, the local community of Kapseret is distressed by high levels of poverty and other related outcomes like high rates of crime, poor education, etc. It is estimated that $50 \%$ of the local population lives below the poverty line (Kimutai, 2007). The Church is overwhelmed by this poor reality of the local community, thereby unable to fully respond to her mission as an agent of development at the local level. She does not have adequate resources to enable her to initiate local community development projects that can bring economic transformation in the affected people's lives. It is against this backdrop that this study sought to investigate the influence of African Inland Church (AIC) initiatives on community development in Kapseret Sub-County, Kenya.

\section{General Objective}

The objective of the study was to evaluate the empowerment of women for economic development in the AIC, Kapseret sub county Uasin Gishu, Kenya

\section{Research Questions}

i. How does empowerment of women add to economic development in the African inland church, Kapseret sub county Uasin Gishu?

\section{Literature Review}

This chapter looks at the theoretical framework, the conceptual framework and empirical review

\section{Theoretical Framework}

The study was guided by Alternative Development Theory

\section{Alternative Development Theory}

This study was guided by ADT developed by Preston in (1999). The theory seriously takes into account the participatory community model, which focuses on a people-centred approach to development where people are able to meet and satisfy their own needs (Hamilton \& Ruta, 2009). The theory enucleates a sustainable approach to development. According to Hamilton (2009), alternative development theory recognizes the people themselves as agents of development; it recapitulates the efforts of the of people and incorporating them to participate in defining their own destiny while creating new paths for their own realization in the development process.

People-centred approach to development ensures that various talents of members are captured in the development process since sustainable development requires a collective effort from various institutions, including churches. Another fundamental element of alternative development theory is explained by Hettne (2005). He explains that alternative development is committed to local solutions to local problems, taking into account the cultural development practices of the involved communities. The theory is relevant to the study in that it is in agreement with the Word of God in Hebrews 10:24-25 and Romans 12:16:

"Let us think of ways to motivate one another to acts of love and good works. And let us not neglect our meeting together, as some people do, but 
INTERNATIONAL JOURNAL OF ACADEMIC RESEARCH IN BUSINESS AND SOCIAL SCIENCES Vol. 10, No. 11, 2020, E-ISSN: 2222-6990 @ 2020 HRMARS

encourage one another, especially now that the day of his return is drawing near" (Hebrews 10:24-25).

"Live in harmony with one another; do not be haughty, but associate with the lowly never be conceited" (Romans 12:16)

The concepts in the scriptures go beyond economic growth to the transformation of their entire social fabric of the community as the goal of development (Korten, 2003). Korten advocates that future socio-economic development should depend on achieving the transformation of institutions, people, values and behaviour consistent with social realities.

Thus, the AIC as a social institution is an agent of development as expressed in her transformative development projects in Kapseret Sub-County. The projects are meant to bring integral human development based on the Christian approach. As pointed out by Hettne (2005), the Church can only have a legitimate and significant role to play when focused in a local and particular cultural context and when guided by a sound theological rationale explicit in the Holy Scriptures. The AIC, because of her close interaction with the people, who are most affected by poverty, has an immense influence on development on the people she serves (Ayiemba et al., 2013).

In Korten's (2003) view, a meaningful transformation must address three basic needs of the community: Justice, sustainability and inclusiveness, which the Church should advocate for in socioeconomic development of her people. These elements, put together, are to enhance the quality of life for all members of society, without the exclusion of others (Keogh \& MacLeod, 2012). This development paradigm shift to people-centred for sustainability as indicated by the above Scriptural texts, calls for an integrated approach to development whereby all development agents government, non-governmental organizations, community and faith-based organizations and also the local community itself should all collaborate in the development process of the community in Kapseret Sub-County.

However, the gap in this theory is that it does not directly explain the role of the church in community development, even though it takes into account community participatory method. It only emphasizes the collective efforts of various institutions. This gap in the theory led the study to opt for the social capital theory.

\section{Empirical Review}

\section{Church and Women Empowerment Initiatives for Development}

Women are the majority in society and the Church, but unfortunately, they are pushed to the traditional mentality where they have taken up supportive roles in serving the Church and expected to have their greatest joy and sense of fulfilment from being wives and mothers. Under this conservative prediction of women, they are not regarded as the greatest agents of economic development of society; this erroneous regard of women has condemned their self-worth to servitude. It should be noted that women's empowerment signifies appreciative, respect for selfworth, and awareness of women's skills and the ability for social change. Kiriti et al. (2006) explain that today, there is an increasing awareness that addressing the restrictions on women's economic empowerment is central in reaching lasting, inclusive, and sustainable economic growth, poverty decrease, food security, and the great achievement of gender equality. The biblical message is that God created male and female in his image and likeness. This was meant for union and 
INTERNATIONAL JOURNAL OF ACADEMIC RESEARCH IN BUSINESS AND SOCIAL SCIENCES Vol. 10, No. 11, 2020, E-ISSN: 2222-6990 @ 2020 HRMARS

complementarity; in the Spirit, there is neither male nor female. The book of Galatians (3:28) explains that the Lord looks on the hearts of His new creatures and, therefore, does not discriminate when He offers His love and privileges. This implies that women are not excluded from any of God's promises nor callings merely because of their sex.

Women's empowerment plays a major role in driving down inequality between men and women; it reduces inequality by relaxing the constraints women go through, increases the resources available to families, and finally reduces women's vulnerability. Furthermore, according to Narayana (2006), there can be no community-based development without the consideration of the place of women in it. Investing in women has a potent multiplier effect on productivity, efficiency, and economic growth of households and society. Datta and Kornberg (2002) explain that women's full participation in the economy drives better performing and more resilient businesses and supports economic growth and wider development goals for nations.

Reducing the barriers that women face to participating in their economic development and increasing their productivity, self-worth, and earnings give them a chance to contribute to society and their respective families meaningfully. Chaudhuri (2009) on the trends of women's empowerment in Asia identified women's participation in decision-making of the issues affecting them and society as paramount if women have to incur development. This is important because development also implies listening to the voices that work for society's same goals. There will be proper development if the other agent of development is not listened to or given a chance to exploit his/her potentialities.

Unfortunately, as Abuom (2001) observes, poverty among women is growing faster, particularly in Sub-Saharan Africa, than in any other part of the planet. Women are excluded in many sectors of the economy: education, politics, decision-making processes, wage-rates, etc. Chaves (2010) claims that women face tenacious discrimination in micro-finance credit offers, such that their power for business and self-employment are rendered insignificant in the global economy. Chaves (2012) further clarifies that this exclusion leads many women without basic rights such as selfdetermination, access to basic needs like clean drinking water, sanitation, medical care, and decent employment. However, he adds that even though the Church does much to empower women through various programs, the Church's contribution as an institution is only one factor that should be complemented by other institutions like the political society, cultural organization, et cetera.

The above views are supported by Serote et al. (2001), who maintain that women are subsumed within patriarchal controls and have no independent access to resources such as land, job opportunities, etc., thereby making them the most suffering human groups. Kothari and Minogues (2002) claim that the exclusion of women in the development process increases poverty levels and insecurity, thereby giving rise to economic inequalities and insecurities among sexes. Further, they add that the exclusion of women in socio-economic development has deep negative community implications. This implies that women should be key actors in the development process. The Church supports and encourages women entrepreneurs, including farmers, and helps them create more sustainable incomes. They are providing inclusive and innovative services and resources, including to microentrepreneurs and smallholder farmers in the formal and informal sectors. This is perceived to improve the viability and profitability of women in society.

Reuther (1988), in the quest to address the struggle for the inclusion of women, states that the New Testament church is an exodus community, not simply from the historical occasion of servitude, but is the ultimate exodus of the people of God from conditions and attitudes that exclude other members of society and subjecting them to the conditions of servitude. All should be involved in the 
INTERNATIONAL JOURNAL OF ACADEMIC RESEARCH IN BUSINESS AND SOCIAL SCIENCES Vol. 10, No. 11, 2020, E-ISSN: 2222-6990 @ 2020 HRMARS

economic development of society. The value of girls and women (Abuom, 2001) must be expanded beyond their definition as potential child-bearers and caretakers to active role players and participants in the economic development of the societies in which they live.

Serote et al. (2001) urge that there should be a change of attitude in men and construct new identities based on gender sensitivity if society has to develop equitably. But this cannot be realized independent of other institutions like the Church with her different women empowerment initiatives that can bring balanced socio-economic development. On this, Zak and Knack (2011) explain that the Church's ability to empower women has been considered an important factor in community development. Putnam (2009) argued that this is fundamentally important because women perform 66 percent of the world's development workforce. Increasing the involvement of women in economic development leads to an increase in their household income. This consequently leads to broader and inclusive economic protection.

\section{Conceptual Framework}

The study made a recap of all variables, capturing the independent and dependent variables, each with its indicators that ground various claims made.

Independent Variables

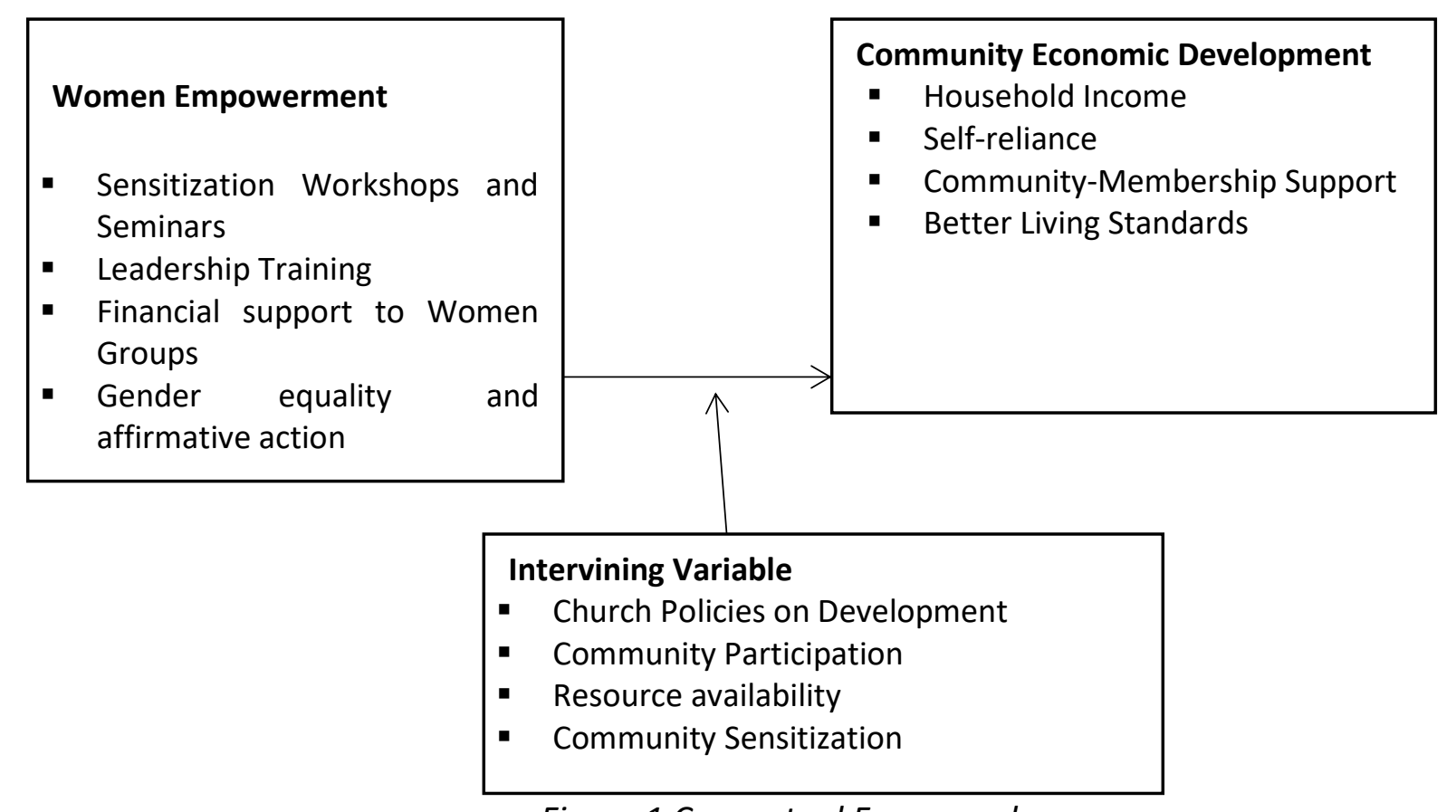

Figure 1 Conceptual Framework

\section{Research Methodology \\ Research Design}

The study employed the Community-based Qualitative Research (CBQR) method. This method provided a good learning process in understanding the church's mandate and involvement in community development. While carrying out the exercise, the study adopted a descriptive research design. Descriptive design helped in analyzing themes related to the influence of African Inland 
INTERNATIONAL JOURNAL OF ACADEMIC RESEARCH IN BUSINESS AND SOCIAL SCIENCES Vol. 10, No. 11, 2020, E-ISSN: 2222-6990 @ 2020 HRMARS

Church initiatives on community development. The descriptive design in this study was intended to describe, examine, and explain the church's contribution to human economic development in the African inland church, Eldoret West District Church Council Uasin Gishu County. The indicators described included: education, women empowerment, church finances, and church projects for human development. This design informed the gathering of adequate and accurate information, analysis, and presentation of that data, and finally, its interpretation (Orodho, 2003).

\section{Target Population}

The study considered a heterogeneous population; it targeted 2157, which was clustered as follows: pastors, church members, chiefs, and sub-chiefs (members that attend the 42 AIC churches in Kapseret sub-county). The study's clusters of informants were considered to have informative knowledge of the influence of the characteristics of Anglican Church initiatives on community development in the study area. The study targeted a population of 2157 respondents. The target population is presented in Table 1

Table 1 Target Population

\begin{tabular}{lll}
\hline Category & Target population & Percentages \\
\hline Pastors & 42 & 1.9 \\
Church members & 2100 & 97.4 \\
Chiefs & 5 & 0.2 \\
Sub-chiefs & 10 & 0.5 \\
Total & $\mathbf{2 1 5 7}$ & 100.0 \\
\hline
\end{tabular}

Source: Kapseret sub-county (2017)

\section{Sample Size and Sampling Techniques}

This section will cover how sample size was arrived at and the formula used to calculate. It also presented the sampling technique used to select the respondents who participated in the study.

\section{Sample Size}

According to Mugenda (2009), a sample size of $10 \%$ is suitable for a population exceeding 1000 , whereas a sample size of $30 \%$ is suitable for less than 1,000 . However, for a population of 100 and below, the researcher should take $100 \%$. Thus, this study adopted a sample of $10 \%$ for all the 42 AIC churches in the Kapsaret sub-county, as shown in Table 2 below.

Table 2 The Sample Size

\begin{tabular}{llll}
\hline Target group & Target number & Sampling procedure & Sample size \\
\hline Pastors & 42 & $42 \times 1$ & 42 \\
Church Members & 2100 & $2100 \times 0.1$ & 210 \\
Chiefs & 5 & $5 \times 1$ & 5 \\
Sub-chiefs & 10 & $10 \times 1$ & 10 \\
& & & $\mathbf{2 6 7}$ \\
\hline Total & $\mathbf{2 1 9 4}$ & & \\
\hline
\end{tabular}

Source: Researcher (2017) 


\section{Sampling Techniques}

For the stratum of Church members, using the above formula, the study used a simple random sampling technique. This was to ensure equitable distribution, as illustrated in table 2 above. Church members were considered the unit of analysis in this study, and thus $97 \%$ of the expected sample size, which translated to 210 respondents, was considered from this stratum. This was appropriate because of its wider coverage that represented various study objectives, thus giving objectivity of the research findings. For other clusters, purposive sampling was used to pick all the 42 pastors of the AIC churches, the 5 chiefs, and 10 sub-chiefs. This was because of their expertise, church and administrative roles in regard to development in the area.

\section{Research Instruments}

Informed by Kumar (2014), data collection methods in this study considered the socio-economic aspects of the targeted population. To address this concern, the study employed two data collection tools: the questionnaire and interview guide.

\section{Questionnaire}

The constructed questionnaire had both closed and open-ended questions covering all the concerns of the study objectives. The questionnaire was given to the Church members. The questionnaire was used to collect data from Church members considered to either directly or indirectly benefited from Church development projects. Respondents were requested to fill the questionnaires, which were then collected for analysis.

\section{Interview Schedule}

Interview schedules were adopted for the study, and it was carried with the pastors, chiefs, and subchiefs. They were the key informants of the study. The choice of this tool for this cluster was informed by Johnson (2017), who explains that interviews are the primary means of acquiring information in many qualitative studies, and they are particularly useful in community-based qualitative research (CBQR). The goal of the interviews was to identify and obtain participants' views about the role the church plays to improve people's well-being through social-economic development. The interviews were planned meeting with a semi-structured interview guide, and it captured the study population's expertise. The interview schedule was used to collect information from pastors, chiefs, and sub-chiefs.

\section{Data Processing and Analysis}

Above, it was claimed that the study employed the Community-based Qualitative Research (CBQR) method with a descriptive research design. Based on the claim, the researcher employed content analysis (Kumar, 2014), whereby the study analyzed the content of the questionnaire and the interviews to identify main themes that emerged from the responses received. Its main purpose was to build themes and opinions about the church and development.

After analyzing the themes' content, the researcher described the findings and processed them by use of Statistical Package for Social Science (SPSS) version 23.0 and descriptive statistics for quantitative data analysis. This enables evaluation and description of the study variables of church initiatives and community development, focusing on content analysis on the emerging themes related to development. The analyzed data was later on presented through narration or verbatim 
INTERNATIONAL JOURNAL OF ACADEMIC RESEARCH IN BUSINESS AND SOCIAL SCIENCES

Vol. 10, No. 11, 2020, E-ISSN: 2222-6990 @ 2020 HRMARS

presentation method. The analyzed data presentation was through tables, graphs, pie charts, and bar charts for easier interpretation.

\section{Findings and Discussions}

\section{Empowerment of Women for Economic Development}

The second objective of the study was to evaluate women's empowerment for economic development in the African inland church, Eldoret West District, Kapsaret sub-county, Uasin Gishu County. The results are shown in Table 3.

Table 3 Empowerment of Women for Economic Development

\begin{tabular}{|c|c|c|c|c|c|c|c|c|c|c|c|c|}
\hline \multirow[t]{2}{*}{ Statement } & \multicolumn{2}{|l|}{ SD } & \multicolumn{2}{|l|}{ D } & \multicolumn{2}{|l|}{$\mathrm{N}$} & \multicolumn{2}{|l|}{ A } & \multicolumn{2}{|l|}{ SA } & \multicolumn{2}{|c|}{ TOTAL } \\
\hline & $\mathbf{F}$ & $\%$ & $\mathbf{F}$ & $\%$ & $f$ & $\%$ & $\mathbf{F}$ & $\%$ & $f$ & $\%$ & $\mathbf{F}$ & $\%$ \\
\hline $\begin{array}{l}\text { The church has } \\
\text { sensitization workshops } \\
\text { and seminars which } \\
\text { empower women in the } \\
\text { society }\end{array}$ & 6 & 3.4 & 15 & 8.5 & 15 & 8.5 & 87 & 49.4 & 53 & 30.1 & 176 & 100 \\
\hline $\begin{array}{l}\text { The church provides } \\
\text { leadership training to } \\
\text { women for economic } \\
\text { development }\end{array}$ & 4 & 2.3 & 8 & 4.5 & 13 & 7.4 & 113 & 64.2 & 38 & 21.6 & 176 & 100 \\
\hline $\begin{array}{l}\text { The church provides } \\
\text { financial support to } \\
\text { women groups for } \\
\text { economic development }\end{array}$ & 12 & 6.8 & 8 & 4.5 & 39 & 22.2 & 81 & 46.0 & 36 & 20.5 & 176 & 100 \\
\hline $\begin{array}{l}\text { The church involves in } \\
\text { gender equality and } \\
\text { affirmative action which } \\
\text { empower women for } \\
\text { economic development }\end{array}$ & 4 & 2.3 & 4 & 2.3 & 44 & 25.0 & 64 & 36.4 & 60 & 34.1 & 176 & 100 \\
\hline
\end{tabular}

The findings shown in Table 3 indicate that the majority (79.5\%) of the respondents asserted that the church has sensitization workshops and seminars for women's empowerment in society. There were $11.9 \%$ (21) of the respondents who disagreed, claiming that the church is not involved in women's sensitization in the area. The attempts to empower women are in agreement with Chaves (2010), who contests that two-thirds of the world's illiterate are women. Thus, the ability of the church to empower women is an important factor in community development. KINFP from church 19 and 25 revealed that:

The benefits that women get when they participate in church empowerment initiatives are diverse and could range from education, income generation to mutual support.

Study findings from interviews indicate that the empowerment of women through sensitization by the church serves as avenues through which they are able to raise their income, enhance productivity, and improve their material and social well-being. The finding implies that church empowerment initiatives serve as entry points for development partners through which development is channeled 
INTERNATIONAL JOURNAL OF ACADEMIC RESEARCH IN BUSINESS AND SOCIAL SCIENCES Vol. 10, No. 11, 2020, E-ISSN: 2222-6990 @ 2020 HRMARS

to the community. Further, members can share their experiences, inspire, and motivate fellow community members. The findings are consistent with Ravider and Narayana (2006), who assert that there can be no community-based development without the consideration of the place of women in it. Investing in women has a potent multiplier effect on productivity, efficiency, and economic growth of households and society. While Datta and Kornberg (2002) explain that women's full participation in the economy drives better performing and more resilient businesses and supports economic growth and wider development goals for nations. The results are further echoed by WagenfeldHeintz (2009), who state that the social benefits that churches bring to communities, which include providing help to poor and vulnerable individuals in the community, improving marriage relationships, decreasing violence among women, increasing moral community obligations, and promoting charitable contributions and volunteering are the basis of community social development. An increase in women's status in society makes them productive members in the areas of the economy, education, and property ownership (Alam, 2011).

On leadership training, as illustrated in table 8 , also shows that $85.8 \%$ (151) of the respondents agreed that the church provides leadership training to women for economic development, whereas $6.8 \%$ (12) disagreed. This concurred with the findings from the interviews, as noted by the key informants:

Church provides women with leadership training, creates jobs for the women in the community, and women's group has incorporated into the church to enable women to save and invest in economic activities. It also guarantees women in community loans and grants.

This concurs with the findings from another informant who stated:

After basic training on managerial skills, projects carried out by women have been successful and have increased economic incomes that have improved household status.

The findings suggest that women empowerment initiatives are useful for various reasons: they provide women with avenues to access information. Such information is key in creating awareness among members on identifying and mitigating social and economic challenges. Empowerment provides women a sense of solidarity and enables them to become self-reliant. There is no development with first sensitization on the communities' priorities, the knowledge to execute the projects, and the basic skills necessary to run those projects. By engaging in empowerment initiatives, women get access to extra earnings, are able to share resources that are geared towards improving their social standing in the community.

The study field findings correspond with the outcomes of the study conducted by Potvin et al. (2011), which stated that churches provide substantial help to communities in direct social services and community volunteering, education and civic skills training, and reduced levels of deviance. These church services complement the government's attempts to expand public funds to the public and incorporate women's contribution to society's economic development. In essence, churches help communities appreciate the attempts feminine face of development and enhance important social projects. The government would need to fund if churches did not provide such support (Brouwer, 2011).

On the provision of economic support to women groups, $66.7 \%$ (117) of the respondents stated that the church provides financial support to women groups for economic development. However, only $11.4 \%$ (20) disagreed, and $22.2 \%$ (39) were neutral. The financial support of women has enabled them to contribute directly to the economic development of society. KINFC1 noted: 
INTERNATIONAL JOURNAL OF ACADEMIC RESEARCH IN BUSINESS AND SOCIAL SCIENCES Vol. 10, No. 11, 2020, E-ISSN: 2222-6990 @ 2020 HRMARS

Women contribute immensely to community development; there is a need to encourage and support women to involve themselves in public life and churches actively. Sustainable community development cannot be complete without the involvement of women at all levels of responsibility in activities for the improvement of the quality of life of their families and communities. Most often, communities involve themselves in various developmental programs without involving the women, and most often, such programs do not succeed.

The finding is supplemented by other key informants (Chiefs and sub-chiefs). They further indicated that project development by and for women is one of the ways of building self-confidence, improving skills, and fulfilling needs through collective action. This is supported by Ellison (2015), who asserts that increased Christian activities lead to a decrease in depression and suicide; it improves mental health and has strong mental health, thus making people more productive. This is further supported by Stairs (2011), who affirm that churches' presence in the community increases the religiosity of locals, which consequently results in positive social contributions for the community. For example, religiosity influences individuals' obligations to perform non-Christian moral acts.

Individuals who are Christian have been shown to have an increased propensity to participate in community-building, moral projects, such as sensitizing others, economical care of the needy, et cetera.

However, the study noted that women are empowered in other areas but not in leadership of community affairs and organization for a wholistic feminine face of development. Taking up of leadership responsibilities for development is instrumental in involving women in decision-making of organizational society, which consequently boost their self-confidence, self-efficacy, civil responsibility and even political efficacy for economic development. KINFC3 noted:

Women in the church have not been empowered in leadership positions either in the community or in the church. therefore, they do not take part in decision-making of organizational society, which in turn reduce self-confidence, self-efficacy, civil responsibility and even political efficacy hence low economic development.

This concurs with Chaves (2012) who established that women have traditionally been stereotyped as ineffective leaders, and therefore, by empowering them they demystify the cultural regard and prove themselves equally productive in community organization. Thus, women empowerment initiatives from churches gives women opportunities to be actively involved in development of society, thereby enabling them to fully exploit their potential for the good of society. Thus, it is necessary that women participate in community organizations because the essence of participation is exercising voice and choice and developing the human, organizational and management capacity to solve problems as they arise in order to sustain their improvements. Involvement of women in decision-making processes results in their empowerment that leads to a sustainable society.

On gender equality for development, the findings show that majority $(70.5 \%)$ of the respondents stated that the church involve in gender equality and affirmative action which empower women for economic development, whereas $5.7 \%(10)$ disagreed. KINFC3 revealed that:

The churches have ensured that women are aware about concept of affirmative actions, enforcement, employment opportunities and implementation of economic activities. This has built the capacity of women's association by allowing the participation of women freely in different sectors such as political, economic, social, non-governmental and educational opportunity via knowing their right and duties. There is improvement of women's participation in the business and development service. 
INTERNATIONAL JOURNAL OF ACADEMIC RESEARCH IN BUSINESS AND SOCIAL SCIENCES Vol. 10, No. 11, 2020, E-ISSN: 2222-6990 @ 2020 HRMARS

The Scriptures fundamentally support the empowerment of women. Galatians (3:28) explains that women are not excluded from any of God's promises nor callings merely because of their sex. Further, the findings agree with a study by Knack (2012) that women bear a disproportionate burden of the world's poverty, representing 70 percent of the world's poor. They are most at risk of hunger because of the systematic discrimination in education, health care, employment, and control of assets. Poverty implications are widespread for women, leaving many without basic rights such as access to clean drinking water, sanitation, medical care, and decent employment. Religion is only one determinant of women's status and role in society. While Chaves (2012) established that women need to walk a freedom road that is both material and spiritual.

\section{Conclusions and Recommendations}

The study inferred that women's empowerment is important for integral development in Kapsaret Sub-county. This opens ways for them to be involved in decision-making processes at the community level, especially in the Eldoret region, characterized by gender discrimination. Their empowerment is an effective demonstration of the female face of development, which also induces a change in all members of society's attitudes towards women and their role in community life. Requiring and supporting women in community roles has the ability to show that women can be actively involved in the community beyond the immediate confines of their family, which contribute to sustainable development.

The study recommended that the AIC actively make women and the youth the objective of her development project. Women are fully supported through various church programs like training and leadership, starting from the Church than to the wider secular society. This is because women are a large group in the Church. When empowered, they can empower other members in the community; women support families daily. When fully empowered, society can realize the beauty of inclusion of all social groups and genders. Development for it to be integral should also contemplate the feminine face, which includes women's characteristics and contributions. Development is not the sole property of men alone; rather, it is for all society members.

\section{References}

Abuom, A. (2001). Women's Issues in Health and Education. In Faith in Development: Partnership between the World Bank and the Churches of Africa. Oxford: Regnum Books International $111-130$.

Alam, A. (2011). Impact of gender discrimination on gender development and poverty alleviation. Sarhad J. Agric, 27(2), 330-331.

Ayiemba, O. J., Theuri, M. M., \& Mungai, C. P. (2015). The Mandate of the Christian Church in Poverty Alleviation: The Case of the Anglican Church of Kenya (ACK) in Maseno and Winam divisions of Kisumu district, Kenya. In International Research Journal of Arts and Social Sciences, Vol. 4(2), 43-54.

Brouwer, R. C. (2011). Chapter Twelve. When Missions Became Development: Ironies Of 'NGOization'In Mainstream Canadian Churches in the 1960s. In Protestant missions and local encounters in the Nineteenth and Twentieth centuries (pp. 259-291). Brill.

Brown, D. L., \& Schafft, K. A. (2011). Rural People and Communities in the 21st century: Resilience and Transformation. Polity. 
INTERNATIONAL JOURNAL OF ACADEMIC RESEARCH IN BUSINESS AND SOCIAL SCIENCES Vol. 10, No. 11, 2020, E-ISSN: 2222-6990 @ 2020 HRMARS

Chaudhuri, S. (2010). Women's Empowerment in South Asia and Southeast Asia: A Comparative Analysis. MPRA Munich Personal RePEc Archive. University of Wisconsin - Eau Claire, 1.

Chaves, M., \& Tsitsos, W. (2000). Congregations and Social Services: What They Do, How They Do It, and With Whom. Paper presented at the annual meeting of the Association for Research on Nonprofit Organizations and Voluntary Action. December.

Chaves, M. (1999). Congregations' Social Service Activities. Charting Civil Society, No. 6. Washington, D.C: Urban Institute.

Christens, B. D. (2012). Targeting Empowerment in Community Development: A Community Psychology approach to enhancing Local Power and Well-being. Community Development Journal, 47(4), 538-554.

Datta, R., \& Kornberg, J. (2002). Introduction: Empowerment and Disempowerment. In Datta, R. and Kornberg, J. Women in Developing Countries Assessing Strategies for Empowerment. Colorado: Lynne Rienner Publisher, Inc.

Datta, R., \& Kornberg, J. (2002). Women in Developing Countries. Assessing Strategies for Empowerment, Boulder.

Fukuyama, F. (2010). Democracy's Past and Future: Transitions to the Rule of Law. Journal of Democracy, 21(1), 33-44.

Ghai, D., \& Vivian, J. M. (2014). Grassroots Environmental Action: People's Participation in Sustainable Development. Routledge.

Hamilton, K., \& Ruta, G. (2009). Wealth Accounting, Exhaustible Resources and Racial Welfare. Environmental and Resource Economics, 42(1), 53-64.

Heale, R., \& Twycross, A. (2015) Validity and Reliability in Quantitative Studies. Ramsey Lake Road: Laurentian University.

Hettne, B. (2005). Beyond the 'new 'regionalism. New Political Economy, 10(4), 543-571.

Johnson, L. R. (2017). Community-based Qualitative Research: Approaches for Education and the Social Sciences. Thousand Oaks, CA: SAGE.

Kiriti, T., Tisdell C., \& Roy, K. (2006). Institutional Deterrents to the Empowerment of Women: Kenya's Experience. In: Roy, K. and Sideras, J. Institutions, Globalisations and Empowerment. Massachusetts, USA: Edward Elgar Publishing, Inc.

Kumar, R. (2014). Research Methodology: A Step-by-Step Guide for Beginners (4 ${ }^{\text {th }}$ ed.). Thousand Oaks, CA: SAGE.

Kuperus, T. (2011). The Political Role and Democratic Contribution of Churches in Post-Apartheid South Africa. Journal of Church and State, 53(2), 278-306.

Oliver, M., Geniets, A., Winters, N., Rega, I., \& Mbae, S. M. (2015). What do Community Health Workers have to say about their work, and how can this inform improved programme Design? A case study with CHWs within Kenya. Global health action, 8(1), 27168.

Orodho, J. A. (2009). Elements of Education and Social Science Research Methods. Nairobi/Maseno, 2(6), 26-133.

Preston, P. W. (1999). Development Theory: Learning the Lessons and Moving On. The European Journal of Development Research, 11(1), 1-29.

Scazzero, P. (2011). Emotionally Healthy Spirituality: Unleash a Revolution in Your Life in Christ. Thomas Nelson.

Serote, P., Mager, A., \& Budlender, D. (2001). Gender and Development in South Africa in the 1990s. Stairs, J. E. (2011). A Global Approach for the Local Church as Mission Agent and Agency. 
INTERNATIONAL JOURNAL OF ACADEMIC RESEARCH IN BUSINESS AND SOCIAL SCIENCES

Vol. 10, No. 11, 2020, E-ISSN: $2222-6990$ @ 2020 HRMARS

Wagenfeld-Heintz, E. (2009). Faith and its Application to the Practice of Social Work. Journal of Religion, Spirituality \& Aging, 21(3), 182-199. 